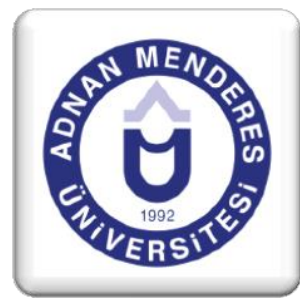

\title{
İÖ 24-9. Yüzyıllar Arası Önasya'nın Kadın Yöneticileri
}

\author{
Emre ERDAN
}

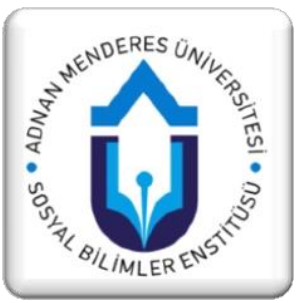

Özet

Tarihöncesi çağlardan günümüze, toplumsal rolü farklılıklar gösteren kadınların 35-40 binyıl öncesinden itibaren kutsal olarak kabul edilmeye başlandığı arkeolojik buluntular aracılığı ile doğrulanabilmektedir. Söz konusu Paleolitik Çağ'dan başlayan ve doğurganlık ile ilişkilendirilen kadının kutsal yönü, özellikle Anadolu toplumları açısından süreklilik arz etmiştir. Neolitik Çağ içerisinde, Çatalhöyük ve Höyücek gibi merkezler aracılığı ile net olarak takip edilebilen inanç sistemi "ana tanrıça" formuna bürünmüş ve tanrıça, doğuran, üreten, bereket saçan ve koruyuculuk gibi yönleri ile tapınım görmüştür. Anadolu ve Önasya'da, binlerce yıl boyunca güçlü bir şekilde yaşam sürmüş olan "ana tanrıça" inancı, belki de aynı şekilde güçlü kadın yöneticilerin ortaya çıkmasında ana sebeplerden biri olmuştur. Öyle ki kadına duyulan saygı, onu yönetici olarak ötekileştirmeden kabulleniş sürecinin ön dayanaklarından biri olmuş olmalıdır. Çalışma içerisinde, günümüzde çeşitli sebeplerle yönetimsel noktalarda görev almakta zorlanan kadınların binlerce yıl önce Anadolu ve yakın çevresinde yer alan coğrafyalardaki güçlü rolü, seçilmiş örnekler aracılığı ile açıklanmaya çalış1lmıştır. İÖ 24. yy'dan, İÖ 9.yy'a Önasya'nın farklı toplumlarında kimi zaman fiili, kimi zaman ise gayri resmi olarak etkin yönetici olan Zugalum, Šibtu, Hatşepsut, Puduhepa ve Sammuramat çalışma içerisinde değerlendireceğimiz kadın yöneticiler olacaktır. Ebla, Mari, Mısır, Hitit ve Asur toplumlarında yönetici olarak görev almış olan bu isimler, tarihin bilinen erken kadın yöneticileri arasında önemli noktalarda yer almaktadırlar. $\mathrm{Bu}$ isimlerin dışında yazılı kaynaklar ve arkeolojik çalışmalar yukarıda değindiğimiz tarih aralığı ve sonrasında da pek çok kadın yöneticinin varlığını bildirmektedirler.

Anahtar Kelimeler: Önasya, Kadın, Tanrıça, Yönetici, Diplomasi.

\section{Woman Rulers of Near East Between $24^{\text {th- }} 9^{\text {th }}$ Centuries BC}

\begin{abstract}
Through archaeological findings it can be confirmed that woman whose social roles varies from prehistoric ages to modernity, were started to be considered as sacred at least 35-40 millenia ago. This sacred aspect of woman which start with Paleolithic Age and related with her fertility was especially continius in Anatolian communities. During the Neolithic Age, religious systems that can be traced with clarity through the settlements like Çatalhöyük and Höyücek took the form of mother goddess and she was worshipped as due to her aspects like being procireant, propagator, fertilizer and protector. Mother goddess belief that influentially continued in Anatolia and Near East for thousands of years might be main reason fort he emergence of powertfull woman rulers in the same way. Respect that was shown to woman must be bases of the process of acquiescence -without alienating- her as a ruler. In this study powerful role of woman in Anatolia and in close surrounding thousands year ago try to be explaine through selected examples though they are encountering problems for various reasons when assuming role in administrave positions in modern times. Zugalum, Šibtu, Hatşepsut, Puduhepa and Sammuramat were the woman rulers who became, sometime de facto sometime unofficial active rulers in a period from $24^{\text {th }}$ to $9^{\text {th }}$ centuries BC within different communities of the Near East are rulers that will be evaulated in this paper. These figures who occupied positions of administrator in Ebla, Mari, Egypt, Hittite and Assyria communities were among the earliest known woman rulers in history. Apart from these names literary sources and archaeological studies confirm existence of many more woman rulers within time span mentioned above an from later periods.
\end{abstract}

Keywords: Near East, Women, Goddess, Ruler, Diplomacy.

\footnotetext{
${ }^{a}$ Adnan Menderes Üniversitesi, Arkeoloji Bölümü, Arş.Gör.Dr., erdanemre@ adu.edu.tr
} 


\section{Giriș}

Tarihöncesi çağlardan bu yana kadının toplumsal rolü büyük değişiklikler göstermiştir. İnsanoğlunun kendini ve çevresinde olanları anlamlandırma çabaları içerisinde kadının doğuran ve üreten rolü, onun yaşam kümesi içerisinde tanrısal bir forma bürünmesini sağlamış, bu haliyle kadın, dinsel inanışların öznesi haline gelmiştir. Çağlar boyu, özellikle bugün yaşadığımız topraklar olan Anadolu coğrafyasının başlıca inanış imgesi olan kadın, bir süre sonra tekelinde bulundurduğu tanrısal gücünü, maskülen kült ve tanrılarla paylaşmaya başlamıştır. Anadolu bağlamında özellikle Neolitik Çağ içerisinde oldukça güçlü bir pozisyonda görülen "tanrıça" kompozisyonu, İÖ 2. binyıla gelindiğinde yukarıda değindiğimiz üzere karşı cins ağırlıklı panteon ile kaynaşmak durumunda kalmıştır. İlgili dönem içerisinde dominant inanç ögesi olma özelliğini, "eş-koca" tanrı ile paylaşmak durumunda kalan tanrıçanın, Demir Çağı başlangıcı itibariyle gücünü, Frigler aracılığı ile olmak üzere "Kybele" kimliğiyle bir kez daha kazandığı görülmektedir. Buna karşın tanrıçanın "yeniden diriliş" olarak tanımlayabileceğimiz bu dönemi çok uzun sürmemiş, kısa bir süre sonra Anadolu, kökleri İÖ 2. binyıl Önasya kültürlerinden beslenen Yunan Panteonu ile sarmalanmıştır. $\mathrm{Bu}$ dönemde erkek egemen panteonun yeniden güçlenmesine karşın, tanrıça inancı senkronizasyon yolu ile Artemis, Rhea, Aphrodite, Demeter gibi kültler aracılığı ile yaşamaya devam etmiştir. Anadolu'nun ve tüm Önasya'nın bu köklü inancı, İS 394 yılında Bizans İmparatoru I. Theodosius'un “Ana Tanrıça” tapınımıyla ilgili törenleri kamuya açık alanlarda tümüyle yasaklamasına dek resmi olarak devam etmiş, bu tarihten sonra da ana tanrıça kült ve uygulamaları ortadan kalkmıştır.

Kadının dini hayat içerisindeki yerinin iyi biliniyor olmasına karşın toplum içerisinde birey olarak ne ifade ettiği konusundaki bilgilerimiz oldukça kısıtlıdır. Anadolu'da yazının kullanılmadığı dönemler için kadının sosyo-kültürel yapılanmadaki yeri yorumlardan ibarettir. Buna karşın Anadolu'nun, başta Hitit yazılı kaynakları olmak üzere yazılı çağları, toplumsal kadın algisı ve rolü ile ilgili son derece önemli bilgiler ile doludur. Yazılı kaynakların tercüme edilmesi sayesinde ulaştığımız bu bilgiler kadınların Hititlerde kanunlar aracılığı ile korunan bir yapıda olduğunu, kral eşlerinin dini törenlerde kocalarıyla beraber "yönetici” olarak görev aldıklarını göstermektedir.

Kadının "yönetici" kimliği, Anadolu için yabancı bir kavram değildir. Örneğin, Hititlerden oldukça önce, İÖ 2400'lü yıllarda içlerinde Anadolu'da yaşam sürmüş bir kadın yöneticinin varlığı bilinmektedir. Zugalum adlı, Ebla Hanedan'ı kökenli bu kadın yönetici, Anadolu tarihinin adı bilinen en eski kadın yöneticisi olması itibariyle son derece önemlidir.

\section{Yöntem}

Çalışmamız içerisinde Anadolu'nun adı bilinen en eski kadın yöneticisi olan Zugalum ve onun döneminde yaşanan gelişmeler önemli bir yer tutmaktadır. Bu bağlamda belki de bir bakıma Zugalum'un açtı̆̆ yolu takip eden kadın yöneticiler, kronolojik bir düzen içerisinde en eskiden, en yakın tarihliye göre sıralanarak incelenecektir. İÖ 24. yy'dan, İÖ 9.yy'a Ebla, Mari, Mısır, Hitit ve Asur toplumlarında yönetici olarak görev almış olan Zugalum, Šibtu, Hatşepsut, Puduhepa ve Sammuramat çalışma içerisinde değerlendireceğimiz kadın yöneticiler olacaktır. $\mathrm{Bu}$ isimler, tarihin bilinen erken kadın yöneticileri arasında önemli noktalarda yer almaktadırlar. 


\section{3. Önasya'nın Kadın Yöneticileri}

\subsection{Zugalum}

Önasya'da "yönetici" kimliğiyle fiilen görev aldığını bildiğimiz en erken kadın yönetici Zugalum'dur. İÖ 24.yy/23.yy içinde Harran (Urfa) kentinin yöneticisi olarak bilinen Zugalum'un Kuzey Suriye'de yer alan ve Tell Mardik adıyla anılan Ebla Krallığı'nın prensesi olduğu bilinmektedir (Yiğit, 2003: 167 vd). Yaklaşık olarak İÖ 2500-2250 yılları arasına tarihlendirilen Ebla metinlerinde siklıkla ismi geçen Zugalum, Harran kentinin başlıca yöneticisi olarak anılmaktadır. Ebla hanedanı ile olan aile bağlarının da etkisiyle güçlenen Zugalum'un sembolik olarak badalum sıfatılla anılan (Erarslan, 2009: 269) kocasından daha geniş yetkilere sahip olduğu belirtilmektedir (Tonietti, 2010: 76-77). Ebla kralı Irkab-Damu'nun çok sayıda kızından biri olduğu bilinen Zugalum'un hanedanlar arası diplomatik evlilik yoluyla Harran Kraliçe'si olduğu bilinmekte, annesinin Irkab-Damu sonrası tahta çıkan Ishar-Damu'nun da annesi olan Dusigu olduğu düşünülmektedir (Archi, 2002: 166). Zugalum ismiyle ilk kez, kendisi henüz 14-18 yaşlarındayken "kralın kadınları" adı verilen listede karşılaşılmaktadır (Tonietti, 2010: 78-79). Bununla beraber Zugalum'dan "kraliçe" olarak söz eden ilk metinler ise Ishar-Damu'nun veziri Ibbi-Zikir dönemine yani yaklaşık olarak İÖ 23. yy’a tarihlenmektedir.

Zugalum ile ilgili yazılı kaynaklar çoğunlukla evlilik, doğum ve ölüm gibi olaylar ve Zugalum'un bu olaylar çerçevesinde katıldığ 1 etkinlikler ile ilgilidir. Bunların yanı sıra Ebla ile karşılıklı olarak gönderilen hediyeler ve bunların kayıtları da önemli bir yer tutmaktadır. Zugalum'un evliliği ile ilgili yazılı kaynaklar yetersiz ve tartışmaya açık durumdadır (Biga, 2010: 48). Tartışmaların odak noktasını Zugalum'dan resmi evliliğe ait olduğu düşünülen yazılı kaynaklardan önce "Harran Kraliçesi" olarak bahsediliyor olması oluşturmaktadır. Bu noktada Zugalum'un daha evlilik gerçekleşmeden "atanmış" olarak bu sıfatı almış olabileceği de düşünülebilmektedir.

Oğlunun doğumu, yazılı kaynaklar aracılığıyla Zugalum hakkında ayrıntılı bilgi sahibi olduğumuz konulardan bir diğeridir. $\mathrm{Bu}$ metinlere göre Zugalum oğlunu doğurduğunda, bunu Ebla'ya bildiren kişi olan Arsi-Ahu (Biga, 2010: 44) zengin hediyelerle onurlandırılmıştır (Weiershäuser, 2008: 192-193). Arsi-Ahu'ya sunulan armağanlar arasında 15 şekel değerinde birer bakır ve altın bilezik yer almaktadır. Bunun yanı sıra Zugalum'un kendisi de armağanlardan payını almış, Ebla krali merkezi kendisini içeriği tekstil ürünlerinden oluşan zengin hediyelerle kutlamıştır (Tonietti, 2010: 80-81).

Zugalum ile ilgili yazıtların bir kısmı, yukarıda değindiğimiz üzere, kraliçenin katıldığ 1 etkinlikler ya da gerçekleştirdiği ziyaretler ile ilgilidir. Dönemin sosyo-politik yapısını anlamamızı sağlayan yazıtlar Zugalum'un Ebla Kraliçe'sinin doğum yapması sonrası onu ziyaret ettiğine dair bilgiler sunmaktadır. Önemli bir olay olduğu düşünülen ve günümüzde "doğum tebriği” olarak devam eden bir geleneğin öncü izlerini yansitan bilgiler Zugalum'un bu ziyareti sonrasında 20 şekel altın ve bir bilezikle ödüllendirildiğini aktarmaktadır (Tonietti, 2010: 82). Aynı metinde, Ebla hanedanından sayılan Burman Kraliçesi Zimini-Ku.Babbar'ın da ziyaret esnasında Zugalum'un ve Ebla Kraliçesi'nin yanında bulunduğu bildirilmekte (Archi, 1996: 89), dönem içerisinde güçlü konumdaki kadınların birbirleriyle olan iletişimlerine dair önemli bilgiler sunulmaktadır. 
Zugalum ile ilgili önemli yazılı kaynaklardan bir diğeri de savaş durumu ile ilgilidir. Zugalum'un Ebla tarafından Ashdar(um)'a karşı düzenlenen sefere katıldığı bilinmekte, ancak metin içerisinde Zugalum'un kocasına dair hiçbir bilgi bulunmamaktadır. Diğer tüm önemli belgeler gibi savaş durumu ile ilgili kaynaklarda da Zugalum'un kocasından bahsedilmiyor oluşu, kendisinin Harran kenti üzerinde, Ebla tarafindan tanınan tek hakim oluşu ile açıklanabilmektedir (Tonietti 2010, 84-85). Badalum ünvanı dışında yazılı kaynaklarda anılmayan kralın adının Iraz-il olduğu yönünde düşünceler bulunmaktadır (Bonechi, 1991: 64, Özfırat, 2005: 36).

Harran Kraliçe'si ve hatta fiilen tek yönetici olarak görülen Zugalum ile ilgili son yazıt oğlunun ölümü ile ilgilidir. Ashdar(um) Seferi sonrası, belki de aynı yıl içerisinde gerçekleştiği düşünülen bu olay sonrasında cenaze töreni için Ebla'dan Harran'a ziynet eşyaları ve tekstil ürünleri gönderilmiştir. Oğlunun ölümü ve akabinde gerçekleşen törene dair bilgilerin ardından Ebla yazılı kaynakları Zugalum hakkında daha fazla bilgi vermemektedir. Bu durum, araştırmacılar tarafindan Ebla'nın tahribata uğradığı sırada Zugalum'un hala yaşıyor ve tahtında oluşu ile ilişkili görülmektedir (Tonietti 2010, 83). Zugalum ile ilgili bir diğer bilgimiz Çığ tarafından aktarılmaktadır. Çığ’a göre, Harran yöneticisi olan Zugalum vasıtasıyla güneyde yer alan "ay kültü” kuzeye taşınmış, aslında bir Ebla prensesi olan Zugalum aracılığı ile Harran bir Ur merkezi haline gelmiş olmalıdır (Çığ, 2006: 79).

Genel olarak değerlendirildiğinde Zugalum'un siyasi, askeri ve bir anne olarak yaşadıkları Ebla metinleri aracılığı ile günümüze değin ulaşmıştır. Metinlerin bize aktardığı bilgiler temsili kral olan kocasının aksine oldukça etkin bir siyasi figür olan Zugalum'un diplomasiye büyük önem verdiğini göstermesi açısından son derece önemlidir. Önasya'da kendi öz hanedanına bağlı diğer merkezler ile iyi ilişkiler içinde bulunan Zugalum, doğum ve ölüm gibi olaylarda gerçekleştirdiği doğrudan ziyaretlerle anılmakta, bu yönü itibariyle Ebla merkezi tarafından sürekli onurlandırılarak ödüllendirilmektedir. Kraliçenin bizzat Ashdar(um) Seferi'ne katılmış olması, salt kendisinin değil, ilgili dönem içerisinde kadının toplumsal yaşamdaki yerini göstermesi açısından son derece önemlidir. Zugalum ile ilgili bilgilerin oğlunun ölümünden sonra kesilmiş olması, Akkad istilası sonucu çöken Ebla krali merkezi ile ilgili olmalıdır. Anadolu'nun Erken Tunç Çağı olarak adlandırdığımız erken bir döneminde "kadının rolü" hakkında aydınlatıcı bir kişilik olan Zugalum, kendinden sonraki kadın yöneticileri de etkilemiş olmalıdır. Öyle ki Zugalum'dan sonra da Önasya'da kadınların yöneticilik vasıfları ve güçlerini kimi zaman kesintilere uğramakla beraber arttırarak devam ettirdikleri görülmektedir.

\section{2. Šibtu}

Zugalum'dan yaklaşık 500 y1l sonra Önasya'da bir başka kadın yöneticinin varlığı bilinmektedir. İÖ 19. yy. sonlarında Halep yakınlarındaki Yamhad Krallı̆̆'nın prensesi olan Šibtu, Kral I. Yarim-Lim'in (İÖ 1780-1764) kızı olarak dünyaya gelmiş, aynı Zugalum'da olduğu üzere diplomatik evlilik bağı ile Marib kralı olan Zimri-Lim (İÖ 1775-1761) ile evlendirilmiştir. Zimri-Lim'in Šibtu'yu, Yamhad kralı olan babası I.Yarim-Lim'den doğrudan bir mektup ile istediği bilinmektedir (Lemmons Deal, 2007: 131). Babası kral I. Yarim-Lim'in sarayında gerçekleştiği bilinen düğün töreni ardından Mari'ye yerleşen Šibtu, zaman içerisinde Mari sarayında etkin bir güç olagelmiştir (Artzi-Malamat, 1971: 75 vd). Mari tabletlerinin aktardığı bilgiler 1şığında kocasının yokluğunda yönetimi devraldığ1

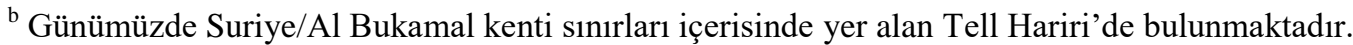


bildirilen Šibtu'nun çok sayıda kişisel mektubu da yapılan arkeolojik çalışmalar neticesinde ele geçmiştir (Leick, 2002: 151).

Šibtu hakkındaki genel değerlendirmeler kraliçenin Mari siyasi tarihi açısından son derece önemli bir politik ve dini figür olduğu yönündedir. Fontaine, Šibtu öncesi Mari'de hiçbir kadının bu denli bir güce erişemediğini, resmi olmasa da Zimri-Lim'in yokluğunda krallığ 167). Šibtu, kendisine tanınan bu geniş haklar bütününü sonuna kadar kullanmış, kocası kralın yokluğunda saray, tapınaklar, işlikler ve saray arşivi üzerinde son derece etkin bir güç haline gelmiştir (Lemmons Deal, 2007: 27).

Batto, Šibtu'nun sadece idari işlerde değil aynı zamanda dinle ilgili konularda da etkin olduğunu belirtmekte, kraliçenin dini törenlerde aktif görev aldığına dikkat çekmektedir. Batto'nun aktardığı ve Mari yazılı kaynaklarına dayanan bilgiler, Šibtu'nun kült heykellerine törenler esnasında eşlik ettiği, kurban törenlerini yönettiği, krala kehanet bildirimlerini ilettiğini göstermektedir (Batto, 1974: 8 vd).

Šibtu ile ilgili bir diğer önemli bilgi onun eşine olan bağl1l $\breve{g ̆}_{1}$ ile ilgilidir. Metinlerde çoğu zaman kocası kral Zimri-Lim ile ilgili endişelerini paylaşan Šibtu'nun kendi sağlık durumuyla ilgili hiçbir zaman şikayette bulunmadığı ve metinlerde kocasına dair en ufak bir kızgınlık taşımadığı belirtilmektedir (Dalley, 2002: 98). Šibtu, tüm bu özellikleriyle ilgili olsa gerek kocası Zimri-Lim'in güvenini fazlasıyla kazanmış, kral mührünün taşıyıcılarından biri haline gelmiştir. Mari tabletlerinden birisinde Zimri-Lim'in karısı Šibtu'ya mührünü gönderdiği, Babil Kralı Hammurabi'ye armağan olarak sunulmak üzere kendisinden şarap talebinde bulunduğu bilinmektedir (Dalley, 2002: 72).

Šibtu ile ilgili ilginç bilgilerden birisi de diplomatik ilişkilerde kocasının varlığına rağmen görev alabiliyor oluşu ile ilgilidir. Ilansura'lı Haya-Sumu ile evlendirdikleri iki kızlarından ilki olan Kiru'nun kendisinden sonra Haya-Sumu ile evlendirilen kardeşi Sibatum'u kıskanması ve akabinde bizzat Haya-Sumu tarafindan tehdit edilmesi sonucunda Mari’ye geri dönüş talebi, Zimri-Lim tarafından ilgilenilmesi amacıyla Šibtu'ya devredilmiş, Šibtu prensesin güvenle Mari’ye geri dönmesine ön ayak olmuştur (Batto, 1974, 42 vd).

Zugalum'dan sonra bilinen ilk etkin kadın yönetici olan Šibtu'nun bir anne ve kraliçe olmak dışında, sarayla ilgili siyasi ve idari konularda da sorumluluk aldığı, bu sorumluluğun kocası kral Zimri-Lim tarafindan arttırıldığı ve bir süre sonra Šibtu'nun dini konularda da önemli bir figür olarak ön plana çıktı̆̆1 görülmektedir.

\subsection{Hatşepsut}

Önasya'nın bir diğer önemli politik kadın figürü Mısır 18. Hanedanlığ1 firavunlarından I. Tuthmosis'in (İÖ 1506-1493) kızı ve üvey kardeşi II. Tuthmosis'in (İÖ 1493-1479) eşi olan Hatşepsut'dur (Dorman, 2005: 87). Kraliyet ailesinde yetişen ve büyüyen Hatşepsut'un çocukluğuna dair bilgiler oldukça sınırlıdır. Hatşepsut'un bu dönemine dair bilgilere, yıllar sonra hükümdarlığını ilan edişini takip eden yıllarda Deir elBahri'de kendi adına yaptırdığı tapınağın üzerinde yer vermesi sayesinde ulaşılmaktadır.

Hatşepsut, ilerleyen yıllarda beklenmedik şekilde eşini kaybetmesinin ardından yerine geçen üvey oğlu/yeğeni III. Tuthmosis'in naipliğini üstlenmiştir. II. Tuthmosis'in İsis 
adlı hiyerarşik açıdan daha düşük seviyedeki bir eşinden doğan ve babası öldüğünde iki ya da üç yaşında olduğu düşünülen III. Tuthmosis'in Misır yasaları gereği tahta çıkışı, Hatşepsut için büyük bir firsat olmuştur. Tarihi metinlerde hırslı ve mücadeleci olarak tanımlanan Hatşepsut, çok geçmeden, bir Amon barkası töreni sırasında tanrıların talebi ile firavun olduğunu ilan ederek törenle taç giymiştir (Hornung, 2004: 90). III. Tuthmosis'in teamüllere aykırı bir şekilde gerçekleşen olay neticesinde, kendisini "dişi firavun" ilan eden naibine onun ölümüne kadar, yaklaşık 15 yıl tahammül ettiği ve onaylamadığı pek çok uygulamasına göz yumduğu düşünülmektedir (Teeter, 2006: 649).

Yöneticiliğinin yedinci yılına kadar tipik bir kraliçe gibi betimlenen Hatşepsut'un bu tarihten itibaren maskülen bir görünüme büründüğü belirtilmekte, fiilen üvey oğlu III. Tuthmosis'in tahtına ortak olduğu ve tapınaklar üzerinde kendisini firavun şeklinde betimlettirdiği bilinmektedir (Dorman, 2005: 88). Hatşepsut'un kendisini "mükemmel tanrıça", "dişi Horus" ve "Ra'nın kızı" şeklinde tanımladığı belirtilmektedir (Hornung, 2004: 92). Günümüzde Mısır'da yürütülen arkeolojik çalışmalar sırasında çok sayıda Hatşepsut betimli stel ve heykel ele geçmektedir. Ele geçen eserlerin bir kısmında Hatşepsut'un bedeni bir şahin gibi görünmektedir (Dorman, 2005: 90-91). Eski Mısır'da Göğün Tanrısı olan Horus ile özdeşleşen bu hayvan şeklinde üretilen eserler, Hatşepsut'un halkın nezdinde kendisini kutsal bir noktaya konumlandırmaya çalıştığını göstermesi açısından son derece önemlidir.

Hatşepsut'un hükümdarlık yılları Mısır siyasi tarihi içerisinde bir durgunluk dönemi olarak tanımlanmaktadır. Dış politikada ülkesine en zayıf zamanlarından birini yaşatan Hatşepsut'un herhangi bir büyük askeri sefer düzenlediğine dair kayıt bulunmamaktadır (Baines-Malek, 1986: 39). Hornung, Hatşepsut dönemini "ülkenin kadınsı hatlara kavuşması" şeklinde tanımlamaktadır (Hornung, 2004: 102). Buna karşın Hatşepsut'un Speos Artemidos Tapınağı'ndaki yazıtlarda Hiksos Hanedanı'na büyük bir kin ve öfke duyduğuna dair bilgiler bulunmaktadır (Baines-Malek, 1986: 39). Dış politikada yaşanan sıkıntılara ve duraklamaya karşın Hatşepsut dönemi, barışçıl olması itibariyle, savaşlardan yorulan Eski Mısır toplumu açısından bir nefes alma, yeniden diriliş dönemi olmuştur. $\mathrm{Bu}$ dönemde bozulan ticari antlaşmalar daha karlı olanlarıla yenilenmiş, daha önceki savaşlar sırasında tahrip olan tapınaklar onarılmıştır. Büyük bir mimari atılım gerçekleştiren Hatşepsut ile ilgili bilgiler III. Tuthmosis'in Megiddo Seferi'nin kayttlarıyla beraber susmaktadır (Keller, 2005: 96).

Hatşepsut, gerek hanedan soyundan geliyor oluşu, gerekse kişiliği itibariyle tarihsel süreç içerisindeki en etkin kadın yöneticilerden birisidir. Kendisini Eski Mısır'ın katı geleneklerinden sıyrılarak firavun ilan edecek denli büyük bir özgüven ve güce sahip olan Hatşepsut'un, Zugalum ve Šibtu'da olduğu gibi dini olgulara bağli olduğu ve hatta bu yönüyle tahta çıkışını kolaylaştırdığı görülmektedir. Eski Mısır'a askeri açıdan zayıf, fakat ticari ve mimari atılımlar bakımından bir o kadar zengin bir dönem yaşatan Hatşepsut döneminde gerçekleşen ya da gerçekleşmeyen siyasi gelişmeler, dolaylı yollarla sonraki dönemleri etkileyen bir sürecin başlangıcını oluşturması bakımından ayrıca önemlidir. "Kadınsı hatlar" olarak tanımlanan devlet politikası sonucunda Eski Mısır'ın uzun süre görmezden geldiği Suriye'de güçlenen küçük merkezlerin Kadeş Kralı etrafinda birleşmesi, Hatşepsut Dönemi'nin hemen sonrasına denk gelir. Bu dönem oldukça güçlenen Mitanni Krallı̆̆ı, Hatşepsut'un naibliğini yaptığı ve tahtına neredeyse ambargo koyduğu III. Tuthmosis'in (ÏÖ 1479-1425) bölgeye 17 sefer yapmasına sebep olacaktır. Devam eden ve domino taşı şeklinde birbirini tetikleyen siyasi gelişmeler bölgede tarihin efsanevi çarpışmalarından biri olan Kadeş Savaşı'nın da fitilini ateşlemiştir. 


\subsection{Puduhepa}

Adını Hitit panteonunun baştanrıçası Hepat'dan alan Puduhepa, Hitit İmparatorluk Dönemi'nin en önemli hükümdarlarından olan III. Hattuşili'nin eşidir (Darga, 2011: 155). İmparatorun otobiyografisi aracılığı ile öğrendiğimiz kadarıyla III. Hattuşili, kardeşi imparator Muwatalli döneminde gerçekleşen Kadeş Savaş1 sonrası, geri dönüş yolunda tanrısına kurban sunmak için yol üzerindeki Lawazantiya kentine gelmiştir. Burada, tanrının talebi doğrultusunda bir Hurri rahibi olan Pentipşarri'nin İștar rahibesi olan kızı Puduhepa ile evlenmiştir (Otten, 1975: 32). Bir bakıma gönülsüzce, sadece tanrının buyruğu ile evlenilen eş, ilerleyen yıllarda kocası ile birlikte Hitit tarihinin en etkin kraliçesi olacaktır. Öyle ki III. Hattuşili otobiyografisinde gönülsüzce evlendiği Puduhepa'dan şu sözlerle bahsedecektir; "Musır Ülkesi'nden geri dönerken, Lawazantiya'ya tanrlya kurban sunmak için gittim ve tanriya görevimi yerine getirdim. Rahip Pentipšarri'nin kızı Puduhepa'yı tanrının isteğiyle eş olarak aldim ve evlendik ve o bize kart-koca sevgisini verdi. Bizim oğullarımız ve kızlarımız oldu. Ayrıca bana Tanrıçam, Beyçem rüyada göründü ve konuştu: 'evinle beraber benim hizmetime girin!' ve tanrlya evim ile beraber hizmet ettim ve var ettiğimiz evimize tanrıça da katıldı ve evimiz gelişti. Bu Beyçem Ištar'ın lütfu idi" (Doğan Alparslan, 2013: 78).

Yaklaşık olarak 60 yaşına kadar Egemen Kraliçe/Tavananna olarak yaşamını sürdürdüğü bilinen Puduhepa'yı Önasya tarihi açısından önemli kılan ögelerin başında diplomasiye olan merakı ve bu konudaki üstün becerileri gelmektedir. Kocası III. Hattuşili, yukarıda değindiğimiz üzere son derece önemli bir imparator olmasına karşın, çocuk yaşlarından itibaren önemli sağlık sorunları ile baş etmiştir (Goetze, 1925: 59). Evliliği sürecinde zaman zaman artan sağlık sorunları sonucunda taht, kısmen de olsa Puduhepa tarafından kontrol altına alınmıştır. III. Hattuşili, karısı Puduhepa'nın üzerine fazlaca düşmesi sonucunda, bugün tıp biliminde hypochondriac olarak adlandırılan hastalık hastalığı/kuruntusuna yakalanmıştır. Bunun sonucu olarak Puduhepa kocasının hasta olduğu zamanlarda devlet ve din işlerine ilgi duymuş, kadın-erkek eşitlik ilkesine dayanarak ülkenin yönetiminde, özellikle de dini konularda söz hakkı edinmeye başlamıştır (Darga, 2011: 175).

Puduhepa'nın Hitit toplumuna etkileri yukarıda değindiğimiz üzere dini konularda yoğunlaşmış görülmektedir. Bir Hurri rahibesi olan Puduhepa, Hitit panteonunda derin izler bırakmıştır. Bryce tarafından "reform" olarak tanımlanan bir dizi atılım Puduhepa aracılığı ile gerçekleştirilmiş ve bu sayede kalabalık Hitit panteonunun düzen içerisine getirilmesine çalışılmıştır. Puduhepa'nın panteonu düzenleme çalışmalarındaki başlıca yöntemi Hitit panteonunda var olan tanrı/tanrıçaların Hurri benzeşleriyle eşitlenmesidir. Bu yolla Hitit kültürünün baş tanrıçası Arinna Hepat'a, Gök Tanrı ise Teşup'a dönüşmüş, zamanla eşleştirme yoluyla Hitit panteonu Hurrileşmeye başlamıştır (Bryce, 2003: 152-153).

Diplomatik ilişkiler, Puduhepa'nın uzmanlık alanlarından bir diğeridir. Yukarıda değindiğimiz üzere kocası III. Hattuşili'nin hasta olduğu dönemlerde imparatorluğu yöneten bir siyasi kimlik olarak karşımıza çıkan Puduhepa'nın kendisine ait, ve kocası III. Hattuşili ile ortak kullandığı mühürler bulunmaktadır. Puduhepa'nın diplomatik ilişkilerdeki etkin rolü Kadeş Savaşı sonrası gelişen Hitit-Mısır ilişkileri kapsamında net olarak izlenebilmektedir. Süreç içerisinde düşman toplumdan, kardeş ülke konumuna gelen Misır ile olan yazışmaların bir kısmının bizzat Puduhepa tarafından gerçekleştirildiği bilinmektedir. Bu yazışmalardan biri Puduhepa'nın uluslararası siyasi konumunu göstermesi açısından son derece önemlidir. II. Ramses tarafından Hitit sarayına gönderilen metinde 
Puduhepa'dan "kız kardeşim” olarak bahsedilmekte, II. Ramses, Puduhepa'dan gelinin başına sürülmek üzere iyi kokulu yağ göndermesini istemektedir.

III. Hattuşili'nin hükümdarlık dönemi büyük çapta bir barış ve imar çağıdır. Tahtı hile yoluyla ele geçirmesi sonucunda sürekli bir paranoya döngüsü yaşayan ve çevresinde başka düşman olsun istemeyen III. Hattuşili döneminde Hitit diplomasi ağı genişlemiş, bunda kraliçe Puduhepa'nın da büyük rolü olmuştur. Hattuşili ve özellikle Hattuşili'nin siyasi anlamda çok büyük yetkilerle donattığı karısı Puduhepa'nın özel çabaları sonucu dönemin iki süper gücü olan Hitit-Mısır ilişkileri ilerlemiş, krallar birbirlerine "kardeşim" diye hitap etmeye başlamışlardır. Hızla gelişen ilişkilere bir de II. Ramses'in Hattuşili'nin kızı Şauşganu ile evlenmesi eklenince hanedanlar arası akrabalık bağları da kurulmuş, hatta II. Ramses bir mektubunda Hitit İmparatorluğu'na veliaht olma istediğini dile getirmiştir. Gitgide müttefik güçler haline gelen Hitit-Mısır ülkeleri arasındaki ilişkiler, Puduhepa'nın bir rüyasında gördüğü gibi (Van Den Hout, 2005: 5), rüyadan yaklaşık bir yüzyıl sonra M.Ö. 1200 'lerde daha önce değindiğimiz "deniz halkları” sebebiyle yıkılışına kadar aynı dostane çizgide sürmüştür.

Puduhepa, her ne kadar kullanmayı sevmiyor olsa da Tavannana ünvanı ile kocasının ölümünden sonra da Hitit tahtında etkin bir güç olagelmiştir. Oğlu IV. Tuthaliya döneminde, gelininin entrikaları sonucu imparatorun hastalığına sebep olmak suçundan yargılanmak zorunda kalsa da, bu olaydan aklanan Puduhepa siyasi gücünü korumuş, ülke içerisinde kimi davalarda yargıç olarak fiili görevler almaya devam etmiştir (Brandau-Schickert, 2003: 182183).

\subsection{Sammuramat}

Çalışmamız içerisinde değerlendireceğimiz son kadın yönetici olan Sammuramat, ya da bilinen diğer ismiyle Semiramis, İÖ 9.yy sonları, İÖ 8. yy başlarında Yeni Asur İmparatorluğu'nu yönetmiş, önemli bir tarihsel kişilik olarak karşımıza çıkmaktadır. Babil Prensesi olarak doğan, III. Salmanasar'ın kızı, V. Şamsi-Adad'ın karısı ve III. AdadNirari'nin annesi olan Sammuramat, dönem içerisinde oldukça etkin bir politik kişilik olması ve hakkında çok sonraları üretilen mitoslar ile ünlüdür (Leick, 2002: 143).

Sammuramat'ın tarihsel süreç içerisinde, ülke yönetimindeki rolü hakkındaki en kapsamlı bilgimiz, Kummuhi ile Gurgum arasında sınırında bulunan Pazarcık Steli üzerinde yer alan yazıttan gelmektedir (Fuchs, 2008: 74). Oluşturulma tarihi olarak İÖ 805 tarihinin önerildiği stel üzerinde, "Adad-nirari'nin annesi, Šamši-Adad'ın hanımı Sammuramat'ın ve Asur'un kralı" ifadesi önemlidir (Y1ldırım, 2010: 127). Alışılmışın dışında, kraldan sonra anılan ilk kişi olması (Fuchs, 2008: 74), Sammuramat'ın toplumsal rolü hakkında bilgi vermektedir.

Öncüllerinden farksız olarak Sammuramat'ın ülke işlerinde sorumluluk alarak güçlenmesi, kocasının sağlık problemleri yaşadığı süreç ve özellikle ölümü ardından gerçekleşmiştir. Sammuramat'in, oğlu III. Adad-Nirari erişkin yaşa gelene kadar yönetimi üç ya da beş yıl süresince fiilen sürdürdüğü bilinmektedir (Jackson Laufer, 1999: 359). Assur'da adına üretilmiş bir anı steli üzerinde büyük kral ve yöneticilerle ismi bir arada anılan Sammuramat'ın yönetim süreci içerisinde yaptıklarına dair arkeolojik kayıtlar oldukça kisitlidır. 
Sammuramat, Yunan yazılı kaynaklarına Semiramis adıyla girmiştir. İÖ 1. yy’da yaşamış olan tarihçi Diodorus Siculus, Sammuramat'ın Babil'i yeniden ayağa kaldırdığı ve muazzam bir şehir kurduğunu belirtmektedir. Ermeni yazılı kaynaklarında da adı geçen bir figür olan Sammuramat, Asur kontrolündeki Urartu Ülkesi’nin yeniden inşasını sağlayan kişi olarak anılmaktaysa da, arkeolojik kaynaklar bu iddiayı desteklemekten çok uzaktır (Jackson Laufer, 1999: 359). İS 5. yy'da yaşamış olan Ermeni tarihçi Khorene'li Musa, Sammuramat'ın aşık olduğu genç uğruna Urartu coğrafyasına bir sefer gerçekleştirdiğini, savaş esnasında aşık olduğu gencin öldüğünü, bunun akabinde tanrıların Sammuramat'a bir başka genç erkek gönderdiğini, birbirlerine aşık olan çiftin bugün Tuşpa Kalesi etrafinda görkemli bahçelerle süslü bir kale yaptırdığını anlatmaktadır. Günümüzde Şamram (Semiramis) Kanalı olarak adlandırılan su yoluna yakın bir noktada yer alan Tuşpa Kalesi, Khorene'nin aktardıklarının aksine Sammuramat tarafindan değil, İÖ 840-830 yılları arasında hüküm sürmüş olan Urartu Kralı I. Sardur tarafindan inşa edilerek, yönetim merkezi haline getirilmiştir (Öğ̈̈n, 1970: 36).

\section{Değerlendirme ve Sonuç}

Çalışma içerisinde tarihsel süreçte, farklı uygarlıklarda yönetici sıfatıyla görev almış kadınların özellikleri ve çalışmaları kısaca açıklanmaya çalışılmıştır. Yazılı kaynakların aktardığ̣ bilgiler 1şığında Anadolu'nun Erken Tunç Çağı olarak tanımlanan erken evrelerinde Zugalum adlı bir kadın yöneticinin varlığının bilinmesi oldukça önemlidir. Kadının toplumsal hayattaki rolünün salt arkeolojik veriler ve buluntuların yorumlanması yoluyla açıklanmaya çalışıldığı, Anadolu'da daha yazının kullanılmadığı bir döneme denk gelen Zugalum'un yöneticilik yılları, kadının en eski çağlardan bu yana etkin bir güç olageldiğinin en önemli kanıtları arasında sayılmalıdır.

Yazılı kaynaklar, Zugalum'u takip eden yıllarda, Önasya'da pek çok kadının yönetimde etkin bir güç haline geldiğini göstermesi açısından son derece ilginç bilgilerle doludur. Sirasıyla Šibtu, Hatşepsut, Puduhepa ve Sammuramat, yaşadıkları dönem ve kültür bölgeleri içerisinde önemli sayılabilecek faaliyetlere katılmış, tarihin çalkantılı zamanlarında ağır sorumluluklar üstlenmişlerdir.

Ortak yönleri itibariyle dikkat çeken benzerlikleri bulunan kadın yöneticilerin hemen tamamının soylu ailelere mensup bireyler olduğu görülmektedir. Bunlar arasında yalnızca Puduhepa'nın farklı sosyal statüsü dikkat çekmekte, bir dini liderin, başrahibe ünvanlı kızı olarak Hitit sarayına gelin gittiği bilinmektedir. Çalışma içerisinde değerlendirdiğimiz Hatşepsut'un, doğduğu topraklarda hüküm süren tek kadın yönetici olduğunu belirtmek gerekir. Doğuştan gelen kazanımlarını iyi değerlendiren Hatşepsut'un anılan kadın yöneticiler arasında en kudretlisi olması, hanedan ailesinden gelmesi itibariyle şaşırtıcı olmamalidır.

Kadın yöneticiler, Hatşepsut haricinde diplomatik evlilikler yoluyla gittikleri topraklarda hüküm sürmüştür. Önasya' da diplomatik evlilikler, özellikle İÖ 2. bin yıl içinde oldukça önemli bir yere sahiptir. Zira birçok ülke aralarındaki sorunların çözümü için bu yola başvurmuş, kız alıp vermeler ile hanedanlar arasında kan bağları kurulmuştur. Ancak Misır bu konuda çifte standarda sahiptir ve hep tek taraflı davranmıştır. Misır, birçok ülkeden kız almış olmasına karşılık hiçbir zaman başka bir ülkeye kız vermemiştir. Hatşepsut'un önlenemez yükselişinin arkasında yatan sebeplerden birisi de Mısır'ın bu 
tutumu olsa gerektir. Bu sayede Hatşepsut ülkesinde kalarak yükselmiş, tarihi domino taş1 gibi etkileyen olaylar silsilesinin başlangıç noktası olmuştur.

Kadeş Savaşı'na giden yolu farkında olmaksızın aralayan Hatşepsut'un aksine, Puduhepa savaş sonrası diplomasi trafiğinin başlıca ana aktörü olmuştur. Teamüllerin ve alışılmışın dışında diğer ülke kral ve eşleriyle bizzat temas kuran Puduhepa'nın ünlü Kadeş Barış Antlaşması'nın bugün elimizde olmayan gümüş orijinalinde mührünün bulunduğu bilinmektedir. Krala bu denli eş güçlere sahip olan Puduhepa'nın Hitit panteonunu sadeleştirmesi ve bu sayede Hitit çekirdek coğrafya kültürünü kendi kökeni olan Hurri kültür etkisi içerisine sokmuş olması, onun tarihsel süreç içerisinde ne denli etkili olduğunun en önemli kanıtları arasında yer almaktadır.

İnsanoğlunun varoluşundan bu yana, süreç içerisinde doğuran, üreten ve koruyan rolü ile "ana", yani "kadının" metamorfozu, tanrılaşmış soyut kavramlar dışına çıkarak onun yönetebilirlik vasfiyla yeniden ve tekrar tekrar tarih sahnesine çıkmasıyla tamamlanmış, kadın, erkek egemen anlayışın tabularını defalarca yıkmıştır. Bazen bir ülke, bazen ise sadece bir nesne, genel tanımlama ile kısaca "var olanın", kendisi tarafından sürdürülebilir ve iyiye doğru geliştirilebilir olduğunu defalarca kez kanıtlayarak "doğruya" imza atan kadının Önasya tarihindeki rolünün, ilerleyen yıllarda ortaya çıkarılacak yeni bulgularla artarak destekleneceğinden şüphe bulunmamaktadır.

\section{KAYNAKÇA}

ARCHI, A. (1996) "Les comptes-rendus annuels de métaux (CAM)", Amurru 1, 73-99.

ARCHI, A. (2002) "Jewels for the Ladies of Ebla", Zeitschrift für Assyriologie und Vorderasiatische Archäologie, Vol. 92-2, 161-199.

ARTZI, P. - MALAMAT, A. (1971) "The Correspondence of Šibtu, Queen of Mari in ARM X," Orientalia $\quad 40,75-89$.

BAINES, J. - MALEK, J. (1986) Eski Mısır, çev. Z. Aruoba ve O. Aruoba, İstanbul.

BATTO, B. F. (1974) Studies on Women at Mari, Baltimore.

BIGA, M. G. (2010) "War and Peace in the Kingdom of Ebla (24th Century B.C.) in the First Years of Vizier Ibbi-zikir under the Reign of the Last King Išardamu", Quaderni di Vicino Oriente V, 39-57.

BONECHI, M. (1991) "Onomastica dei Testi Di Ebla: Nomi Propri Come Fossili-Guida?" Studi Epigrafici e Linguistici sul Vicino Oriente Antico 8, Verona, 59-79.

BRANDAU, B. - SCHİCKERT, H. (2003) Hititler: Bilinmeyen Bir Dünya Imparatorluğu, çev. N. Mertoğlu, Ankara.

BRYCE, T. (2003) Hitit Dünyasında Yaşam ve Toplum, çev. Müfit Günay, Ankara.

ÇIĞ, M. İ. (2006) İbrahim Peygamber: Sümer Yazılarına ve Arkeolojik Buluntulara Göre, İstanbul. 
DALLEY, S. (2002) Mari and Karana: Two Old Babylonian Cities, New Jersey.

DARGA, M. (2011) Anadolu'da Kadın: On Bin Yıldır Eş, Anne, Tüccar, Kraliçe, İstanbul.

DOĞAN ALPARSLAN, M. (2013) “Hititler’de Kadın”, Aktüel Arkeoloji 32, 70-79.

DORMAN, P. F. (2005) "Hatshepsut: Princess to Queen to Co-Ruler", Hatshepsut: From Queen to Pharaoh, Eds. C. H. Roehrig, R. Dreyfus, C. A. Keller, 8791.

ERARSLAN, A. (2009) "Local Settlement Transitions in Southeastern Anatolia during the Late Third and Early Second Millennium BC", Altoriental. Forsch., 36-2, 268-292.

FONTAINE, C. (1999) "A Heifer from thy Stable." Women in the Hebrew Bible: a Reader, 159-178.

FUCHS, A. (2008) "Der Turtān Šamš̄i-ilu und die große Zeit der assyrischen Großen (830746)", Die Welt des Orients 38, 61-145.

HORNUNG, E. (2004) Ana Hatlarıyla Misır Tarihi, çev. Z. A. Y1lmazer, İstanbul.

JACKSON LAUFER, G. M. (1999), Women Rulers Throughout the Ages: An Illustrated Guide, California.

KELLER, C. A. (2005) "The Joint Reign of Hatshepsut and Thutmose III" Hatshepsut: From Queen to Pharaoh, Eds. C. H. Roehrig, R. Dreyfus, C. A. Keller, 96-101.

LEICK, G. (2002) Who's Who in the Ancient Near East. New York.

LEMMONS DEAL, B. (2007) Divine Queenship and Psalm 45, Unpublished Phd Thesis, Fort Worth.

OTTEN, H, (1975) Puduhepa, Eine hethitische Königin in ihren Textzeugnissen, Mainz.

ÖĞÜN, B. (1970) Van 'da Urarlu Sulama Tesisleri ve Şamran (Samiramis) Kanall, Ankara.

ÖZFIRAT, A. (2005) Eski Çă̆'da Harran, İstanbul.

TEETER, E. (2006) "Hatshepsut and Her World", American Journal Of Archeology, Vol.110, 649-653.

TONIETTI, M. V. (2010) "The Expedition of Ebla against As`dar(um) and the Queen of Äarran", Zeitschrift für Assyriologie und Vorderasiatische Archäologie, Vol. 100-1, 56-85.

VAN DEN HOUT, T. (2005) "A Hittite Queen and James Henry Breasted: Two Dreams Come True", The Oriental İnstitute News \& Notes 184, Chicago, 5-6. 
WEIERSHÄUSER, F. (2008) Die königlichen Frauen der III. Dynastie von Ur.

YILDIRIM, N. (2010) "Anadolu'da Bulunan Yeni Asurca Belgeler-Neo-Assyrian Documend Found in Anatolia" Ankara Üniversitesi Dil ve TarihCoğrafya Fakültesi Tarih Bölümü Tarih Araştırmaları Dergisi, 2010, 119-135.

YİĞİT, T. (2003) “İlk Tunç Çağı'nın Son Evresinde Anadolu'nun Siyasal Görünümü”, Ankara Üniversitesi Dil ve Tarih-Coğrafya Fakültesi Tarih Bölümü Tarih Araştırmaları Dergisi, Cilt: 21, Sayı: $\quad 33,167-182$. 